\title{
Different Approach of Policies in E-Waste Management System: A Case Study of India in Comparison to Germany
}

\author{
Silvia Refina Dewi ${ }^{1}$ \\ ${ }^{1}$ Department of Environmental Health, Universitas Indonesia, Depok, Indonesia
}

\begin{abstract}
.
With a total of 44.7 million tonnes of electronic waste (e-waste) produced worldwide in 2016, only approximately $20 \%$ of e-waste documented to be recycled in formal sectors. As many as $80 \%$ of undocumented e-waste which both informally recycled and piled up in landfill has huge side effects towards the health of societies and environment. Policies have contributed to be the guideline in implementing e-waste management system within the country. Thus, in this article India and Germany are chosen in order to compare the different policies existed in both country that result in different management of e-waste. India as the fourth country who generates most ewaste in the world produces 2 million e-waste in 2016. However, only 0.036 million tonnes of ewaste managed by India in 2016-2017. Whereas 95\% of India e-waste is recycled informally. In other hand, Germany ranks in the fifth place of countries with most e-waste producer (1.9 million tonnes) successfully recycles their e-waste up to $39 \%$ in 2016 . The method used in comparing these two conditions is a case study with data collected from various sources. As result, standards of equipment and recovery as well as recycling of e-waste have become the key differences in India policies in compared to Germany. This condition can be addressed by increasing the standards, increasing knowledge sharing, maximizing the output of e-waste management, stating clear sanctions to societies and companies. Besides, strengthening the implementation and monitoring of policies issued should become India's strategy in achieving its e-waste management target.
\end{abstract}

Keywords: case study; e-waste; Germany; India; policy 


\section{Introduction}

Technological development is progressing faster than ever. Consumers are now becoming more consumptives in buying and replacing more electronics products, neglecting the need and importance on purchasing the electronics devices. Technologies will initially bring two effects; benefit the consumers in doing everyday life in an easier way but also damage the environment as well as bring harm to people affected by the waste. As many as 44.7 million tonnes of electronic waste (e-waste) were generated globally in 2016 (Baldé, Forti, Gray, Kuehr, \& Stegmann, 2017). With only $20 \%$ ( 8.9 million tonnes) of e-waste collected and properly recycled, the rest ( $80 \%$ of e-waste which amounts to 35.8 million tonnes) is undocumented. The undocumented e-waste is predicted to both thrown into residual waste (1.7 million tonnes) and traded as well as recycled with improper system (34.1 million tonnes) (Baldé et al., 2017).

India which is inhabited by more than 1,370 million people has successfully become the largest electronic waste producer in the Southern and South-Eastern Asia region with total production of 2 million tonnes of e-waste (Baldé et al., 2017; Worldometers, 2019). Besides, India is said to rank in the fourth place of countries which generate most e-waste in 2018 (Environmental Technology, 2018). With the prediction of increase of e-waste up to 5.2 million tonnes by 2020 added by the additional weights from importing e-waste, India offers eight States (Maharashtra, Tamil Nadu, Uttar Pradesh, Karnataka, Gujarat, Haryana, Telangana, Rajasthan) that contribute most in its ewaste recycling systems (Shenoy, 2018). However, India only successfully manage its 0.036 million tonnes of e-waste in 2016-2017 (Lahiry, 2019). With this number, India has involved more than one million workers where in Delhi alone about 25,000 workers are doing the e-waste recycling (Bhattacharya, 2019; Perkins, Drisse, Nxele, \& Sly, 2014). One of side effects of recycling in India especially in informal sectors is that out of 260 children in India taken their blood tested in 2014-2015, the result shows that children with elevated blood lead level (BLL) amounts to $44.2 \%$ whose mean value is $55.7 \mu \mathrm{g} / \mathrm{dL}$ (Chaudhary, Firdaus, Ali, \& Mahdi, 2018).

In contrary, Germany which generates e-waste as many as 1.9 million tonnes and ranks in fifth place of countries that generate most e-waste has reached the recycling rate up to $39 \%$ in 2016 (Tiseo, 2019). The urge stated by European Commission to submit rates of collection, recycling and recovery has helped to motivate Germany in increasing its rates. In 2017, Germany has passed collection rate's target given by WEEE directives for 45.08\% (Umwelt Bundesamt, 2019). Besides collection rate, WEEE directives along with Germany's Electrical Products Act also set rates target which diverse depending on type and class of devices. Not only in collection rate's target has Germany complied, but also Germany has achieved and maintained all rates since 2007 (Umwelt Bundesamt, 2019).

\section{Methods}

The method used is by descriptive method with case study research, where policies regarding ewaste management in India and Germany are chosen to be the objects of the research. India and Germany are chosen due to both countries have huge amount of e-waste produced, however 


\section{SCIENCE, ENGINEERING \& TECHNOLOGY}

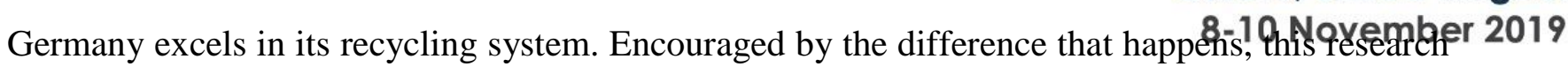
is done in looking forward to disparities that exist in policies of both countries.

\section{Results}

Data for this case study report are collected from various sources that are related to the policies exist in each country regarding e-waste management.

Table 1: Comparison of e-waste management policies in India and Germany

\begin{tabular}{|l|l|l|}
\hline Indicators & India & Germany \\
\hline $\begin{array}{l}\text { Standards of } \\
\text { equipment used }\end{array}$ & Low standard & High standard \\
\hline Recovery of e-waste & Hazardous to environment and societies & Bring benefit to environment and societies \\
\hline
\end{tabular}

\section{Discussion}

Policies in each country are made to become guidelines that later adopted by each element in the societies so that the goal of making related policies can be achieved. In solving the issues caused by improper e-waste management, policies are made to tackle these issues. The issues of e-waste management become public health issue due to its spread not only to an individual, but to one even some communities in a specified area. Pollution caused by pollutants that degrade quality of air, water, soil can have both direct and indirect impacts to the societies. Therefore, providing good policies that are applicable and compatible is the first step in achieving the goal of desired e-waste management.

In India, many equipment used in managing e-waste is far from good standard. Although the number of licensed recycling infrastructure increases, the quality of the facilities is still not propriate (Centre for Responsible Business \& Green Electronics Council, 2018). Lack of good standards will encourage the recycling sectors especially informal sectors not having the urgency to step up their equipment. Thus, side effects of low standard of e-waste management equipment have contributed to negative impacts brought to the environment, workers and surrounding societies. Besides, India's investment in recovery and recycling e-waste in large-scale management is still little. A lot of India recycling centres still use manual sorting. Further, the methods of extracting e-waste used have high potential towards the health of societies and environment. Some methods used are open-air incineration and acid leaching (Gaikwad, 2019).

Whereas in Germany, equipment used in handling e-waste have passed the standard set in its laws. Licenses are also given in making sure the quality of the equipment used, including transport licenses in mobilizing the e-waste (German Law Archieve, 2013). In terms of recovery, incinerators are used by Germany after the process of recycling e-waste. The energy gotten from e-waste is generated into another form of energy such as steam energy, electricity or hot water. 


\section{SCIENCE, ENGINEERING \& TECHNOLOGY}

These other forms of energy can be used by societies and industries (Cave, 2019)xfphds, \beiteflesingdom can get direct impacts of activities that they have done in participating in the e-wastel pallagenneher 2019

As making good policies become the first step, monitoring of the implementation of the policies made become the second step in assuring the goal of the policies achieved. In its implementation, India's implementation towards e-waste management policies is still far behind Germany. India as developing countries face various problems including financial conditions and lack of awareness

from its societies. Whereas in Germany, recycling has become a habit and culture of Germany, not only in recycling e-waste, but other waste including plastic, papers, bottles and so on. Thus, with good support from the country in its financial form as well as good habit that is embedded in its societies to take their part in the waste management process, the implementation of policies exist in Germany can be easily applied and can easily increase the recycling rate of e-waste in the country.

\section{Solutions}

India should soon solve this situation in order to save the health of its societies and the environment from various pollutants coming from improper managing of e-waste. Some solutions that can be implemented by India are:

1. Increasing the standards of equipment used in handling e-waste into international standards. This should cover standards of managing e-waste both in formal and informal sectors. Thus, providing various alternatives in technologies and tools used can be very useful in achieving the goal of increasing the standards in managing e-waste.

2. Increasing knowledge sharing between countries as a reference in improving the recovery of e-waste that is suitable to be implemented by India.

3. Maximizing the output of e-waste management to give back to societies. By making a transparent report of the distribution of advantaged gotten from e-waste management, societies will be encouraged more to take their part in e-waste management.

4. Strengthening the implementation and monitoring of policies that India has issued and committed to be implemented. Thus, this will encourage in the reduction of gaps between what's written and what's implemented.

5. Stating clear sanctions to societies and companies who break the rules written in the laws. Besides, involving impacted societies in order to them being able to make report caused by activities related to e-waste management can be used as consideration in strengthening the monitoring of e-waste management.

\section{Conclusion}

Not tackling the issue of e-waste management meaning letting pollutants bring its negative effects to the societies and environment. The issue of improper management of e-waste finally becomes the issue of public health that needs to be solved soon. Both India and Germany have had comprehensive policies regarding its e-waste management. However, the implementation of India's e-waste management falls behind Germany due to some factors that are affected by its policies such as the standards stated for the equipment used in handling e-waste and the recovery 


\section{SCIENCE, ENGINEERING \& TECHNOLOGY}

of e-waste. Besides, the factors of lacking monitoring and low enforcement of policies issuyed haber 2019 caused the implementation of e-waste management still becomes the issue. Thus, India can implement several things that can help foster its e-waste management including (1) increasing the standards of equipment; (2) increasing knowledge sharing between countries; (3) maximizing the output of e-waste management; (4) strengthening the implementation and monitoring of policies; (5) stating clear sanctions to societies and companies who break the rules. By implementing those solutions, India is expected to improve its e-waste management, thus the rate and quality of ewaste management can be more progressive.

\section{Acknowledgment (TNR 12pt. bold)}

The author would like to thank God The Almighty for giving a lot of grace and blessing in the making of this paper. The author also thanks International Academic Conference on Science, Engineering and Technology (RSETCONF) for holding this event. Lastly, the author would like to express her gratitude to her parents and Lisa Maisyurah for always supporting her and believing in her.

\section{References}

Baldé, C. ., Forti, V., Gray, V., Kuehr, R., \& Stegmann, P. (2017). The Global E-waste Monitor 2017. Retrieved September 25, 2019, from https://collections.unu.edu/eserv/UNU:6341/GlobalEwaste_Monitor_2017_electronic_single_pages_.pdf

Bhattacharya, A. (2019). Can something good come out of India's worsening e-waste problem? Apparently yes. Retrieved September 25, 2019, from Quartz India website: https://qz.com/india/1586449/indias-e-waste-crisis-could-create-recycling-manufacturing-jobs/ Cave, S. (2017). Recycling in Germany (No. NIAR 485-16).

Centre for Responsible Business, \& Green Electronics Council. (2018). Capacity building opportunities and end of life management criteria for a voluntary consensus standard. Retrieved from https://greenelectronicscouncil.org/wp-content/uploads/2018/11/GEC-CRBCapacityBuilding-Opportunities-Report-FINAL-Oct-2018.pdf

Chaudhary, S., Firdaus, U., Ali, S., \& Mahdi, A. (2018). Factors Associated With Elevated Blood Lead Levels in Children. Indian Pediatrics, 55, 15-18.

Environmental Technology. (2018). Which Countries Produce the Most E-Waste? Retrieved September 25, 2019, from https://www.envirotech-online.com/news/healthandsafety/10/breaking-news/which-countries-produce-the-most-e-waste/46470

Gaikwad, V. (2019). Improving E-Waste Management in India. Retrieved September 25, 2019, from https://www.aii.unimelb.edu.au/publications/very-short-policy-brief/improving-ewastemanagement-in-india/

German Law Archieve. (2013). Closed Substance Cycle Waste Management Act 
2nd International Conference on Research in

\section{SCIENCE, ENGINEERING \& TECHNOLOGY}

Oxford, United Kingdom

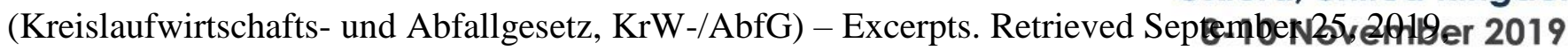
from https://germanlawarchive.iuscomp.org/?p=303

Lahiry, S. (2019). Recycling of e-waste in India and its potential. Retrieved September 25, 2019, from https://www.downtoearth.org.in/blog/waste/recycling-of-e-waste-in-india-and-itspotential64034

Perkins, D. N., Drisse, M. B., Nxele, T., \& Sly, P. D. (2014). E-Waste : A Global Hazard. Annals of Global Health, 80(4), 286-295. https://doi.org/10.1016/j.aogh.2014.10.001

Shenoy, J. (2018). India among the top five countries in e-waste generation:ASSOCHAM-NEC Study. Retrieved September 25, 2019, from India Times website: https://timesofindia.indiatimes.com/india/india-among-the-top-five-countries-in-ewastegeneration-assocham-nec-study/articleshow/64448208.cms

Tiseo, I. (2019). Recycling rate of e-waste in Germany 2009-2016. Retrieved September 25, 2019, from Statista website: https://www.statista.com/statistics/632731/e-waste-recycling-germany/

Umwelt Bundesamt. (2019). Electrical and electronic waste. Retrieved September 25, 2019, from https://www.umweltbundesamt.de/en/topics/waste-resources/product-stewardshipwastemanagement/electrical-electronic-waste\#textpart-1

Worldometers. (2019). India Population. Retrieved October 15, 2019, from https://www.worldometers.info/world-population/india-population/ 